\title{
Timing Trades And Mutual Fund Investors
}

\author{
Richard H. Fosberg, (E-mail: fosbergr@wpunj.edu), William Paterson University
}

\begin{abstract}
Recently, a number of well known mutual funds advisors, including Strong, Putnam, and Bank of America, have been accused of or admitted to allowing selected institutional investors to engage in timing trades with the shares of some of the mutual funds they manage. The news media has generally taken the position that timing trades reduce the wealth of other fund investors. In this study, I show that timing trades can either increase, decrease, or leave unchanged fund shareholder wealth. Which outcome results will depend on specific timing trader and fund characteristics such as the frequency and accuracy of timing trader speculation, the trading of other fund shareholders, the return on the fund's security portfolio, and how much a mutual fund must increase its cash holdings to cover the transactions of timing traders. Consequently, whether timing traders harm other fund shareholders is an empirical question.
\end{abstract}

\section{Introduction}

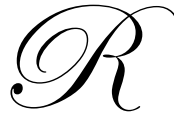

ecently, a number of well known mutual funds advisors, including Strong, Putnam, Janus, and Bank of America, have been accused of or admitted to allowing selected institutional investors to engage in timing trades with the shares of some of the mutual funds they manage (Solomon, Hechinger and Lauricella (2003)). Mutual fund advisors are companies hired to manage a mutual fund's portfolio of securities. Timing trades are rapid (daily) buying and selling of mutual fund shares in order to speculate on short-term movements in the value of a mutual fund's portfolio. Timing traders attempt to exploit correlations between international stock markets, stale (out of date) pricing of the fund's securities, and other strategies to make short-term trading profits. These timing trades were allowed to occur by the funds even though most mutual funds explicitly discouraged frequent trading of their fund's shares in their prospectuses. The media coverage of these timing trades has focused primarily on the losses that timing traders are alleged to inflict on other fund shareholders (Damato (2003)). However, since the stock market is not a zero-sum game, profitable timing trades do not necessarily result in equivalent losses for other fund shareholders. In this paper, I will attempt a more detailed analysis of the financial effects of timing trades on mutual fund investors in order to ascertain when timing traders can cause losses for the other fund shareholders. No attempt will be made here to discuss fairness, legal or behavioral issues that timing trades raise. Although these issues are important and merit serious discussion, I will limit my discussion to the effects of timing trades on mutual fund shareholders' wealth.

\section{Mutual Fund Trading}

Even though most mutual funds discourage frequent trading of their shares, their advisors allowed timing trades by some institutional investors in selected mutual funds in return for large investments by the institutional investors in other mutual or hedge funds managed by the advisor. The advisor benefited from this arrangement because the investments made by the institutional investors in their other mutual or hedge funds generated extra advisory fees for the advisor. However, there is a cost to the advisor for allowing timing trades if, as is alleged, these trades lower the value of the assets held by a mutual fund. In that case, the mutual fund advisor would lose some advisory fee income from the affected funds. Economically rational advisors, therefore, would only allow timing trades in their mutual funds if they generated a net increase in advisory fee income.

In mutual fund trading, orders to buy or sell shares received before 4:00 PM EST (the closing time of most U.S. security markets) are executed at the net asset value (NAV) of a fund share at the close of trading on that day. Orders received after 4:00 PM EST are supposed to be executed at the closing NAV of the fund on the next trading day. The NAV of a mutual fund share, which represents the value of the assets one fund share has an ownership 
claim on, is equal to the market value of the assets the fund owns (cash and securities) divided by the number of fund shares outstanding. If mutual funds could costlessly adjust their portfolios for their daily net cash flows by investing in or selling on a pro rata basis each security in their portfolio at the closing prices of those securities, timing trades (or trades by non-timers) would not affect the NAV of the funds shares and, therefore, would not affect the wealth of any fund shareholder. For example, assume that a no-load mutual fund has 100 shareholders, each of whom owns 10 shares of the fund and the mutual fund's current portfolio that contains $\$ 20,000$ in common stocks as of the close of trading today (day 0). The NAV today of a mutual fund share is $\$ 20$. Assume that all orders to buy or sell fund shares are received before 4:00 PM EST, are executed at the NAV of the fund at the close of trading today, that timing traders are purchasers of 10 shares (invest \$200), and that the value of fund's current portfolio will rise by $5 \%$ tomorrow (day 1). The value of the fund's assets on day 1 will be $\$ 21,210$, the value of its current portfolio on day $1(\$ 20,000 \cdot 1.05)$ plus the day 1 value of the new investment by timing traders $(200 \cdot 1.05)$. The day 1 NAV is $\$ 21.00(21,210 / 1,010)$. Without the timing traders the NAV on day 1 would be $\$ 21.00(21,000 / 1,000)$. The NAV ends up being the same with or without timing trades. This occurs because the timing traders $\$ 200$ investment can be invested at the closing prices of the fund's securities on day 0 and therefore will earn the same rate of return on day 1 as the fund's current portfolio and because there are no transactions costs. The NAV will also be the same in either case if security prices fall on day 1 and/or if timing traders are sellers of fund shares.

\section{Transaction Cost Effect}

Unfortunately, security transactions are not costless and the daily net cash flows cannot be adjusted for at the closing prices of the securities in the fund's portfolio. Transaction costs incurred when buying or selling securities may include brokerage fees, transfer taxes, and administrative costs of adjusting shareholder account records. Also, since daily net cash flows are not known until after the close of trading, the fund's security portfolio cannot be adjusted until the next trading day. Consequently, timing trades can affect the NAV of a funds shares and, therefore, the wealth of the fund's shareholders. However, the existence of these imperfections does not guarantee that fund shareholders will be hurt by the activities of timing traders. As an example, assume that timing traders are net purchasers of zero shares. Define the net purchases of shares $(\mathrm{N})$ by a class of investors to equal the number of shares purchased minus the number of shares sold by that class of investors. If $\mathrm{N}>0$ the investors were net purchasers of shares and if $\mathrm{N}<0$ they were net sellers of shares. If the net purchases of shares by timing traders is zero the fund will not have to adjust its portfolio for the timing traders activities and, consequently, the other fund shareholders will not have to bear any transaction costs (except the cost of adjusting the fund's ownership records) nor will they suffer any capital losses because of the delayed investment in or liquidation of fund securities. This result will hold no matter what happens to security prices on day 1 . Consequently, for timing traders to have a material effect on the wealth of the other fund shareholders they must be net purchasers or sellers of significant numbers of fund shares.

Next, assume that timing traders are net purchasers of zero shares and the other fund shareholders are net purchasers of ten shares. Consequently, all security transactions executed by the fund on day 1 are caused by the actions of the fund's non-timing traders. Tomorrow the fund must invest its net cash inflow of $\$ 200$ in each of the securities in the fund's portfolio and pay the resulting transaction costs. Assume that transaction costs are $.5 \%$ of the value of the securities traded and that security prices do not change on day 1 . At the close of trading tomorrow the fund's security portfolio will be worth $\$ 20,199$, the $\$ 20,000$ value of its current portfolio plus the $\$ 200$ invested by fund shareholders minus $\$ 1(200 \cdot .005)$ in transaction costs, and the fund will have 1,010 shares outstanding. Thus, tomorrow's NAV will be $\$ 19.999$ or .1 cent less than what it would have been if there had not been any net trading of the fund's shares. If non-timing traders had place orders to sell 10 shares, then on day 1 the value of the fund's security portfolio would be $\$ 19,799$ and the number of fund shares outstanding would be 990 . Thus, tomorrow's NAV would be $\$ 19.999$ or .1 cent less than what it would have been if there had been no trading in the fund's shares. The above results would be the same if the timing traders were the net purchasers or sellers of shares and the other fund shareholders were zero net purchasers. Therefore, trades by anyone, timing traders or other fund investors, hurt a fund's investors to exactly the same degree. Fund investors are hurt by any trading of the fund's shares because the resulting transaction costs are born proportionately by all the fund's investors.

Now assume that timing traders are net purchasers of 10 shares and the other shareholders are net sellers of 10 shares. The transactions of the timing traders and the other fund investors exactly offset each other, the net cash 
flow for the day will be zero, no adjustment will be made to the fund's security portfolio, and the NAV of the fund tomorrow will be $\$ 20$. Recall from the previous example that if timing traders are net purchasers of zero shares while other fund investors are either net purchasers or sellers of 10 shares the NAV of the fund will be \$19.999. Consequently, if timing traders' transactions exactly offset those of the fund's other shareholders, timing traders will actually benefit the fund's shareholders by reducing the fund's transaction costs.

To obtain a general solution for the transaction cost effect on fund investors, define $\mathrm{N}_{\mathrm{tt}}$ to be the net purchases of fund shares by timing traders, $\mathrm{N}_{\text {oth }}$ to be the net purchases of fund shares by other investors, $\mathrm{N}_{\text {off }}$ to be the net share purchases by timing traders that are offset by the other fund investors transactions, and TC to be the transaction costs per dollar of securities traded. The net cost to the fund of allowing timing trades (NC) equals the transactions costs the fund will incur if timing trades are allowed less what the transaction costs would be if timing trades were prohibited. If timing trades are allowed the transaction costs the find will incur will be the unoffset net purchases of the timing traders $\left(\left|\mathrm{N}_{\mathrm{tt}}\right|-\mathrm{N}_{\text {off }}\right)$ plus the unoffset trades of the other fund investors $\left(\left|\mathrm{N}_{\text {oth }}\right|-\mathrm{N}_{\text {off }}\right)$ times the fund NAV on day $0\left(\mathrm{NAV}_{0}\right)$ times TC. The absolute value of $\mathrm{N}(|\mathrm{N}|)$ represents the number of shares traded (bought or sold) by the various classes of fund investors. The transaction costs the fund will occur in the absence of timing trades are the transaction costs associated with the trading of other fund investors, $\left|\mathrm{N}_{\text {oth }}\right| \cdot \mathrm{NAV}_{0} \cdot \mathrm{TC}$. Therefore, the change in transaction costs the fund experiences if timing trades are allowed is:

$\mathrm{NC}=\left(\left(\left|\mathrm{N}_{\mathrm{tt}}\right|-\mathrm{N}_{\text {off }}\right)+\left(\left|\mathrm{N}_{\text {oth }}\right|-\mathrm{N}_{\text {off }}\right)\right) \cdot \mathrm{NAV} \mathrm{V}_{0} \cdot \mathrm{TC}-\left(\left|\mathrm{N}_{\text {oth }}\right| \cdot \mathrm{NAV}_{0} \cdot \mathrm{TC}\right)$

Simplifying the right hand side yields:

$\mathrm{NC}=\left(\left|\mathrm{N}_{\mathrm{tt}}\right|-2 \mathrm{~N}_{\text {off }}\right) \cdot \mathrm{NAV} \mathrm{V}_{0} \cdot \mathrm{TC}$

For NC to be greater than zero:

$\left|\mathrm{N}_{\mathrm{tt}}\right|-\mathrm{N}_{\text {off }}>\mathrm{N}_{\text {off }}$

That is, for a fund's investors to be hurt by the activities of timing traders, the net purchases or sales of the timing traders that are not offset by other fund investors net purchases or sales must exceed the net purchases or sales by the timing traders that are offset by the net purchases or sales of the other fund investors. If the inequality in equation 3 is reversed then NC will be negative and fund investors will actually be helped by the activities of timing traders. This will occur when more than half of the timing traders net purchases or sales are offset by the transactions of the other fund investors and, consequently, the fund experiences a net reduction in transaction costs because of the trading of timing traders.

\section{Speculation Effect}

Besides the transaction cost effect discussed previously, timing trades can cause gains or losses for other fund investors if the value of the fund's security portfolio changes before the security portfolio can be adjusted for the transactions of the timing traders. This will usually be the case, since the net purchases or sales of timing traders on day 0 will be adjusted for during day 1 at security prices prevailing at the time. Only in the rare instance in which the day 1 value of the security portfolio was the same as the day 0 value (security prices did not change during day 1) would this not occur. As an example, assume that timing traders believe that on day 1 the value of the fund's securities will rise and they seek to capitalize on this by purchasing 10 fund shares on day 0 (when the NAV is \$20). Further, assume that the other fund investors are zero net purchasers of fund shares and the value of the fund's current (day 0) securities portfolio rises, as forecast by the timing traders, from $\$ 20,000$ on day 0 to $\$ 21,000$ day 1. Further assume that the $\$ 200$ invested by the timing traders is used to purchase securities sometime before the close of trading on day 1 when the value of the fund's security portfolio is $\$ 20,500$. At the end of day 1 the fund will own a portfolio of securities worth $\$ 21,205.88$. The $\$ 21,000$ value of the current portfolio plus the $\$ 204.88$ closing value of the new securities purchased during the day $(200 \cdot(21,000 / 20,500))$. The NAV of the fund tomorrow will be $\$ 20.996$ (21,205.88/1010). Without timing trades the NAV of the fund on day 1 would be $\$ 21$ $(21,000 / 1,000)$. This occurs because the timing traders money is invested after security prices have already risen 
some on day 1 and, therefore, does not get the full day's price appreciation. This lost appreciation is born proportionately by all the fund's shareholders. The transaction cost effect would lower the NAV by a further \$.001. Analogous results are obtained if timing traders believe the value of the fund's portfolio will fall, sell fund shares, and security prices do decline.

If, on the other hand, the timing traders forecast had been wrong and the value of the securities in the fund's portfolio had fallen, a different result would be obtained. Assume that the value of the fund's current security portfolio at the end of day 1 is $\$ 19,000$ and the net cash inflow from timing traders is invested before the close of trading on day 1 when the value of the fund's current security portfolio is $\$ 19,500$. The total value of the fund's as sets on day 1 would be $\$ 19,194.87$ - the $\$ 19,000$ value of the fund's day 0 portfolio plus the $\$ 194.87(200 \cdot 19,000 / 19,500)$ value of the new funds invested by timing traders. The fund's NAV on day 1 is $\$ 19.005(19,194.87 / 1,010)$. Without timing traders, the NAV of the fund on day 1 would be $\$ 19.000(19,000 / 1,000)$. In this case, the other fund shareholders benefit from the activities of timing traders because the funds the timing traders put into the fund are not invested until security prices have fallen somewhat and therefore less money is lost on the timing traders investment than on the securities in the fund's portfolio on day 0 . This loss reduction is shared proportionately by all the fund's investors. Analogous results are obtained if timing traders believe the value of the fund's portfolio will fall, sell fund shares, and security prices rise. I will call the above results the speculation effect on fund shareholders.

In general, the amount of the change in the value of a fund's security portfolio caused by timing trader speculation $(\Delta \mathrm{SP})$, assuming zero net purchases by other fund investors, is:

$\Delta \mathrm{SP}=\left(\mathrm{R}_{\mathrm{tt}}-\mathrm{R}_{\mathrm{s}}\right) \mathrm{N}_{\mathrm{tt}} \cdot \mathrm{Nav}_{0}$

$\mathrm{R}_{\mathrm{tt}}=\mathrm{S}_{1} / \mathrm{S}_{\mathrm{t}}-1$

$\mathrm{R}_{\mathrm{S}}=\mathrm{S}_{1} / \mathrm{S}_{0}-1$

$\mathrm{S}_{0}=$ the value of the fund's current security portfolio on day 0

$\mathrm{S}_{1}=$ the value of the fund's current security portfolio on day 1

$\mathrm{S}_{\mathrm{t}}=$ the value of the fund's current security portfolio at the time when the fund's portfolio is adjusted for the transactions of the timing traders.

Specifically, $\Delta \mathrm{SP}$ is the difference between the return on day 1 on the money invested/withdrawn by timing traders $\left(\mathrm{R}_{\mathrm{tt}}\right)$ and the return on day 1 on the fund's current portfolio $\left(\mathrm{R}_{\mathrm{s}}\right)$ multiplied by the inflow/outflow of cash caused by the timing trader's transactions $\left(\mathrm{N}_{\mathrm{tt}} \cdot \mathrm{Nav}_{0}\right)$. If timing traders speculate correctly about changes in the value of the fund's portfolio, $\Delta \mathrm{SP}<0$, and if the timing traders are incorrect, $\Delta \mathrm{SP}>0$. More specifically, if timing traders are net purchasers of shares and the resulting net inflow of cash is invested after the value of the fund's current security portfolio has increased (decreased) in value, fund shareholder wealth will be diminished (enhanced). If timing traders are net sellers of shares and the resulting liquidation of securities from the fund's current portfolio occurs after the value of the fund's security portfolio has decreased (increased) in value, fund shareholder wealth will be diminished (enhanced).

\section{Cash Balance Effect}

The activities of timing traders have also forced some mutual funds to increase their holdings of cash and, consequently, decrease the amount of money invested in the fund's security portfolio (Pulliam and Lauricella (2003)). This shifting of investment dollars can also affect the wealth of the fund shareholders. I will call this the cash balance effect. Assuming no trading by any fund shareholders on day 0 , the value of the fund's assets on day 1 will be $V_{1}=C_{0}\left(1+R_{c}\right)+S_{0}\left(1+R_{s}\right)$. That is, $V_{1}$ is equal to the amount of cash the firm has on day $0\left(C_{0}\right)$ multiplied by one plus the return the fund earns on its cash balance on day $1\left(R_{c}\right)$ plus the value of the funds security portfolio on day $0\left(S_{0}\right)$ multiplied by one plus the return the fund earns on its security portfolio on day $1\left(\mathrm{R}_{\mathrm{s}}\right)$. All returns are expressed in decimal form. In the long-run, the return the fund earns on the higher risk assets in its security portfolio should exceed the returns the fund earns on its cash balances $\left(R_{s}>R_{c}\right)$. This implies that if timing traders force a fund to increase their cash holdings, this will reduce the investment income the fund earns by causing money to be shifted into low earning cash balances. The change in investment income caused by holding more cash is equal to 
the increase in cash holdings $(\Delta \mathrm{C})$ multiplied by the difference between the return the fund earns on its cash investments and the return the fund's earns on its security portfolio $\left(R_{c}-R_{s}\right)$. In the short-run however, investors can actually benefit if the fund holds more cash. For example, because of the negative returns most funds earned between 2000 and 2002 on their security portfolios, funds forced to hold greater cash balances because of the activities of timing traders would have had smaller losses during this time period than they otherwise would have.

\section{Conclusion}

In sum, the effect of timing traders on fund shareholder wealth is the sum of the transaction cost, speculation, and cash balance effects. Since individually each of these effects can either increase or decrease shareholder wealth, the total change in shareholder wealth that results from timing trader activity can also be positive or negative. A variety of factors including, the extent of the trading activity by the timing traders and the other fund investors, the accuracy with which timing traders can predict changes in the value of the fund's security portfolio, and how much the fund must increase its cash holdings determine the net effect of timing traders on the wealth of other fund investors. For timing traders activities to unambiguously decrease (increase) shareholder wealth less (more) than half of the timing traders net purchases of shares must be offset by other fund investors transactions, the timing traders must correctly (incorrectly) predict the change in the value of the fund's security portfolio, money must be (not be) shifted from the fund's security portfolio into its cash holdings, and the return on the fund's security portfolio must exceed that on its cash balances. If these conditions do not hold, the net effect on fund shareholder wealth will depend on the magnitudes of the three effects. Ultimately, this is an empirical question.

\section{References}

1. Damato, K. “'Timing' at Mutual Funds Can Cost 2\% a Year”, The Wall Street Journal, September 19, 2003.

2. Pulliam, S. and T. Lauricella. "A Fight at Invesco Spotlights the Toll of 'Market Timers' ", The Wall Street Journal, December 2, 2003.

3. Solomon, D., J. Hechinger and T. Lauricella. "Milestone for 'Timing' Scandal", The Wall Street Journal, October 29, 2003. 